\title{
IMPLEMENTASI PUBLIC PRIVATE PARTNERSHIP SEBAGAI USAHA KEBERHASILAN PENGEMBANGAN PARIWISATA DI ERA GLOBAL
}

\author{
Oleh: \\ Nik Haryanti \\ Institut Agama Islam Pangeran Diponegoro Nganjuk \\ nikharyanti1983@gmail.com
}

\begin{abstract}
Abstrak
Tujuan penulisan jurnal ini untuk mengetahui keberhasilan public private partnership dalam pengembangan pariwisata di Indonesia. Penelitian ini menggunakan jens penelitian kepustakaan. Hasil penelitian ini menunjukkan bahwa pengembangan obyek wisata Public Private Partnership (PPP) merupakan hubungan kerjasama antara pemerintah dan pihak swasta sebagai investor dengan berbagai keahlian baik secara teknik, operasional maupun secara inovasi dalam perjalanan bisnis secara efisien dan pemerintah sebagai pembuat kebijakan dalam pembangunan destinasi wisata. Pengembangan pariwisata di Indonesia dengan jalan: membuat program pengembangan destinasi wisata, meningkatkan sarana prasarana wisatawan. Untuk mendapatkan keberhasilan public private partnership dalam pengembangan pariwisata di Indonesia, ada beberapa hal yang harus dilakukan yaitu: 1) menciptakan pariwisata yang siap bersaing, mengupayakan obyek wisata yang siap berkompetisi dengan obyek wisata yang ada di Indonesia. 2) menciptakan pariwisata yang kooperatif yaitu obyek wisata yang bisa menciptakan suasana yang asri dan alami, untuk membuat obyek wisata tersebut dibutuhkan kerjasama antara pemerintah dan pihak swasta agar dapat berperan aktif memberikan pelayanan yang terbaik untuk wisatawan dengan pembangunan berbagai prasarana yang menarik. 3) menciptakan pariwisata dengan koordinasi dan kolaborasi yang baik antara masyarakat, pemerintah dan swasta, agar dapat memberikan karakteristik yang unik yang dapat mengembangkan obyek wisata alam yang murni.
\end{abstract}

Kata Kunci: Public Private Partnership, Pengembangan Pariwisata 
Perkembangan pariwisata di Indonesia sangat pesat, sehingga secara global bekerja sama saling melengkapi perannya dari pihak pemerintah, swasta dan masyarakat untuk meningkatkan pengembangan pariwisata. Pariwisata merupakan industry multyimedia yang melibatkan campur tangan semua pihak (Suardana, 2013). Saat ini periwisata menjadi prioritas utama dalam rangka meningkatkan pendapatan negara di luar migas dan pajak. Dengan demikian Indonesia menjadi salah satu negara berkembang untuk mempromosikan pariwisatanya untuk menarik minat wisatawan asing. Hal ini dilakukan untuk mengenalkan indahnya panorama pariwisatanya. Dampak dari promosi yang dilakukan semakin banyaknya wisatawan asing yang berkunjung d Indonesia (Maharani, 2014).

Indonesia dapat mengembangkan potensinya dari aspek pariwisata, sehingga dapat mengatasi permasalahan tentang penguatan ekonomi melalui devisa atau pendapatan daerah (Pratiwi dan Warsono, 2013). Dengan pariwisata Indonesia yang indah dan nyaman, dapat menumbuhkan daya tarik wisatawan asing untuk datang sehingga dapat menambah pendapatan masyarakat, sehnggat dapat meningkatkan kesejahteraan masyarakat sekitarnya.

Undang-Undang Nomor 10 Tahun 2009 tentang kepariwisataan menjelaskan bahwa pembangunan kepariwisataan diperlukan untuk mendorong pemerataan kesempatan berusaha dan memperoleh manfaat serta mampu menghadapi tantangan perubahan kehidupan lokal, nasional dan global. Pariwisata dalam pembangunan nasional mempunyai peran yang besar, hal ini disebabkan karena dapat menghasilkan devisi dan pendapatan yang diperoleh dari sector pariwisata terkait juga pada penanaman modal asing. Wisatawan asing yang datang di Indonesia, diantaranya adalah wisatawan yang mempunyai hubungan bisnis dengan Indonesia.

Kegiatan pariwisata dilakukan dengan tujuan untuk penyediaan atau usaha pariwisata dan dapat menjadi daya tarik bagi wisatawan. Perindustrian pariwisata apabila di kelola dengan baik dengan peran dari berbagai pihak diantaranya pemerintah, swasta dan masyarakat. Segala pihak saling membantu dan mengembangkan 
pariwisata, sehingga pada akhirnya dapat mensejahterakan masyarakat apabila dikembangkan secara maksimal (Maharani, 2014).

Holik (2016) menyatakan dengan pembukaan baru objek wisata, kegiatan ekonomi di sekitarnya akan dikembangkan. Kreasi pekerjaan akan menyerap karyawan di sektor formal dan non-formal. Ini karena untuk kegiatan ekonomi yang lebih berkembang oleh komunitas dan orang luar (turis), tidak hanya di lokasi pariwisata tetapi juga di ekonomi kegiatan di luar pariwisata. Ketersediaan dana yang cukup tidak mendukung yang besar potensi industri pariwisata sejalan dengan kebutuhan biaya pengembangan yang relatif besar di setiap daerah. Di sisi lain, investasi, khususnya di beberapa daerah, memerlukan khusus fasilitas, layanan dan lisensi yang bersifat pribadi sektor saja tidak dapat menyediakannya (Haddadi, 2015). Karena itu, pemerintah daerah perlu bekerja sama.

Pengembangan periwisata ssuatu daerah dapat meningkatkan kesejahteraan atau perekonomian bagi masyarakat yang dapat dilihat dar berkurangnya jumlah pengangguran di lingkungan pariwisata. Aspek pariwisata yang dikembangkan dapat memberi kontribusi yang besar dalam peningkatan kesejahteraan rakyat sekitar. Hal ni diyakini bahwa pariwisata berfungsi sebagai katalisator pembangunan dan sebagai agent of development yang sekaligus sebagai penggerak utama dalam pembangunan (Latuconsina, Syaukat dan Siregar 2013).

Investasi di suatu destinasi merupakan bagian integral dari kinerjanya, model PPP menantikan investasi dari pemain swasta dengan motif keuntungan untuk mendorong proyek berbasis pariwisata. Hal ini memungkinkan tidak hanya untuk perluasan kapasitas, tetapi juga mendorong peningkatan kualitas, daya saing, produktivitas, dan keberlanjutan. Oleh karena itu investasi dalam hal proyek modal baru dan perbaikan besar merupakan bagian integral dari kinerja tujuan saat ini dan masa depan. Antara 2011 dan 2021, investasi Perjalanan \& Pariwisata global diperkirakan akan meningkat rata-rata $5 \%$ per tahun - atau $73 \%$ secara keseluruhan, lebih cepat dari PDB Perjalanan \& Pariwisata dan pertumbuhan lapangan kerja - untuk mencapai US \$ 1.490 miliar pada tahun 2021. The Bagian industri 
dari total investasi modal diperkirakan hanya akan naik sedikit, sebesar $0,1 \%$ per tahun (Dias, 2014).

(WTTC, 2011) melaporkan berbagai bentuk investasi dalam perjalanan dan pariwisata adalah: 1) Pengembangan akomodasi dan pemeliharaan utama, termasuk bangunan baru dan perbaikan hotel dan rumah liburan; 2) Transportasi penumpang, seperti pesawat terbang dan kapal pesiar, untuk penggunaan pariwisata tertentu; 3) Proyek modal dan perbaikan yang dirancang untuk menarik pengunjung; dan 4) Investasi hijau dalam industri, seperti skema tenaga surya dan retrofit untuk ditingkatkan efisiensi energi. Berikut ni perkiraan tentang investasi perjalanan dan wisata pada tahun 2011 dan 2021 yaitu:

Tabel 1 investasi perjalanan dan wisata pada tahun 2011 dan 2021

\begin{tabular}{|c|c|c|}
\hline 1 & Montenegro & $16.4 \%$ \\
\hline 2 & Singapore & $9.3 \%$ \\
\hline 3 & Azerbaijan & $9.1 \%$ \\
\hline 4 & Thailand & $8.8 . \%$ \\
\hline 5 & India & $8.7 \%$ \\
\hline 6 & Lithuana & $8.5 \%$ \\
\hline 7 & China & $8.5 \%$ \\
\hline 8 & Egypt & $7.8 \%$ \\
\hline 9 & Myanmar & $7.8 \%$ \\
\hline 10 & Fji & $7.6 \%$ \\
\hline
\end{tabular}

Sumber data: Dias (2014)

Tabel di atas menunjukkan Prakiraan WTTC tentang investasi Perjalanan \& Pariwisata antara 2011 dan 2021 menyebutkan bahwa India akan memiliki rata-rata pertumbuhan investasi Perjalanan \& Pariwisata sebesar 9\% pertumbuhan per tahun dan menjadikannya 10 besar negara seperti ditunjukkan pada Tabel 1, India akan menuangkan sebagian besar sumber daya masa depan ke dalam industri ini untuk meningkatkan daya saing globalnya, juga diperkirakan akan melampaui Jepang untuk menjadi investor Perjalanan dan Pariwisata global ketiga tertinggi dengan pangsa 5\% dari investasi global. 
Sejak 1980-an telah diamati bahwa "kemitraan telah mendapatkan popularitas sebagai instrumen untuk perencanaan pariwisata, pembuatan kebijakan, pengembangan masyarakat, pengembangan produk, pemasaran dan manajemen tujuan" (Zapata, 2014). Ada berbagai bentuk kemitraan yang ada dan dapat mencakup penyatuan pemangku kepentingan yang berbeda "dalam kemitraan sukarela formal atau informal untuk meningkatkan daya tarik destinasi regional, produktivitasnya, efisiensi pasar terkait dan pengelolaan pariwisata secara keseluruhan ", termasuk untuk konservasi sumber daya. Hal ini didukung dengan penelitian Rogerson (2016) pentingnya PPP pariwisata untuk meningkatkan daya saing bisnis, peningkatan ekonomi, pembangunan dan kebersihan lingkungan. Dalam pengembangan destinasi pariwisata PPP sebagai salah satu elemen perencanaan wisata. Pengembangan infrastruktur (jalan, penjara, rumah sakit) dan yang terbaru diperluas ke proyek pariwisata sebagai kendaraan untuk transfer risiko ke pihak swasta.

Pengembangan pariwisata tersebut akan dapat terlaksana dengan baik apabila menjalin kerjasama bermitra pada pemerintah swasta atau disebut sebaga public private partnership yang merupakan suatu bentuk perjanjian jangka panjang yang belum maksimal dalam pelaksanaannya, sehingga belum bisa memberikan perjalanan wisata yang menyenangkan (Ikram, 2018). Hal ini disebabkan karena kurangnya komunikasi yang baik antara pemerintah, swasta dan masyarakat untuk segera bertindak dalam meningkatkan pariwisata di Indonesia agar lebih terkenal di manca negara. Dengan demikian, jelas peran kebijakan pemerintah sangatlah dibutuhkan dalam mengembangkan objek wisata. Bermitra dengan pihak swasta karena disebabkan oleh kurangnya dana dan sumber daya pemerintah dalam pengembangan wisata, agar pengembangan dapat berlangsung dengan cepat.

\section{Metode Penelitian}

Penelitian ini menggunakan jens penelitian kepustakaan. Penelitian kepustakaan sebagai suatu penelitian yang dilaksanakan 
dengan mereview dari berbaga jurnal dan buku-buku referensi terkait, yang pada akhirnya dapat dianalisis dan disimpulkan dari berbagai sumber yang didapatkan oleh peneliti tersebut. Pendekatan penelitiannya adalah penelitian kualitatif yang dilakukan dengan berorientasi pada gejala alamiah yang terjadi dan penelitian ini tidak dilakukan di laboratorium. Penelitian yang dilakukan bersifat deskriptif dimana peneliti mengumpulkan kata-kata bukan berupa serangkaian angka untuk penelitian ini yang pada intinya kata-kata tersebut bisa memberikan gambaran atau menyajikan permasalahan dan pemecahan masalah yang ada. Analisis data yang digunakan adalah dengan menganalisis isi, dimana dalam analisis lebih mengedepankan pada menguraikan isi dari berbagai proposisi yang telah ada yang terlahir dari berbagai teori dan analisis sebelumnya yang dilakukan oleh peneliti lain.

\section{Hasil dan Diskusi}

\section{Public Private Partnership}

Public Private Partnership adalah kontrak yang mengikat secara hukum antara dua pihak yaitu lembaga atau badan swasta dan negara atau pemerintah pusat. Dimana dalam perusahaan swasta memiliki tanggung jawab untuk mengambil risiko keuangan yang besar dan menggunakan fasilitas pemerintah untuk memberikan dukungan infrastruktur dan layanan kepada masyarakat umum. Ada juga tren yang muncul dari pemerintah yang membiayai proyekproyek tersebut serta terlibat dalam berbagi risiko keuangan dan pembelian jika diperlukan. Perusahaan swasta pada gilirannya diizinkan untuk mengambil keuntungan dari pengembalian yang mereka dapatkan dengan menyediakan layanan tersebut. Dalam pengembangan obyek wisata Public Private Partnership (PPP) merupakan hubungan kerjasama antara pemerintah dan pihak swasta sebagai investor dengan berbagai keahlian baik secara teknik, operasional maupun secara inovasi dalam perjalanan bisnis secara efisien dan pemerintah sebagai pembuat kebijakan dalam pembangunan destinasi wisata (Fitriyah, 2016). 
Jurnal Dinamika Ekonomi Syariah

http://ejurnal.iaipd-nganjuk.ac.id/index.php/es

p-ISSN: 2654-3567

Public Private Partnership menggambarkan layanan pemerintah atau usaha bisnis swasta yang didanai dan dioperasikan melalui kemitraan pemerintah dan satu atau lebih perusahaan sektor swasta. Skema ini kadang-kadang disebut sebagai PPP (Johnson, 2010). Pemerintah India mendefinisikan P3 sebagai "kemitraan antara entitas sektor publik (otoritas sponsor) dan entitas sektor swasta (entitas hukum di mana 51\% atau lebih ekuitas adalah dengan mitra swasta) untuk penciptaan dan / atau pengelolaan infrastruktur untuk tujuan publik untuk jangka waktu tertentu (periode konsesi) dengan persyaratan komersial dan di mana mitra swasta telah diperoleh melalui sistem pengadaan yang transparan dan terbuka" (Out dan Mmom, 2015) .

PPP melibatkan kontrak antara otoritas sektor publik dan pihak swasta, di mana pihak swasta menyediakan layanan atau proyek publik dan menanggung risiko keuangan, teknis, dan operasional yang substansial dalam proyek tersebut. Dalam beberapa jenis PPP, biaya penggunaan layanan ditanggung secara eksklusif oleh pengguna layanan dan bukan oleh wajib pajak. Dalam jenis lain (terutama inisiatif keuangan swasta), investasi modal dilakukan oleh sektor swasta berdasarkan kekuatan kontrak dengan pemerintah untuk menyediakan layanan yang disepakati dan biaya penyediaan layanan ditanggung seluruhnya atau sebagian oleh pemerintah. Kontribusi pemerintah untuk PPP juga dapat berupa natura (terutama transfer aset yang ada). Dalam proyek yang ditujukan untuk menciptakan barang publik seperti di sektor pariwisata, pemerintah dapat memberikan subsidi modal dalam bentuk hibah satu kali, sehingga membuatnya lebih menarik bagi investor swasta. Dalam beberapa kasus lain, pemerintah dapat mendukung proyek dengan memberikan subsidi pendapatan, termasuk keringanan pajak atau dengan memberikan pendapatan tahunan yang dijamin untuk periode yang tetap.

Public Private Partnership akan terlaksana dengan lancar: 1) Pihak swasta melaksanakan sebagian fungsi pemerintah selama waktu tertentu, 2) Pihak swasta menerima kompensasi atas pelaksanaan fungsi tersebut, baik secara langsung maupun tidak langsung, 3) Pihak swasta bertanggung jawab atas resiko yang timbu 1 akibat 
pelaksanaan fungsi tersebut, 4) Fasilitas pemerintah, lahan atau asset lainnya dapat diserahkan atau digunakan oleh pihak swasta selama masa kontrak (Ikram, 2018).

Tujuan PPP adalah untuk berkontribusi pada integrasi ekonomi, mempercepat pertumbuhan ekonomi dan pembangunan berkelanjutan, melahirkan dan mempertahankan partisipasi sektor swasta dalam proyek-proyek sektor publik tradisional seperti halnya dengan pariwisata dan memperluas akses lokal ke pasar internasional. Untuk mencapai PPP berkelanjutan untuk memastikan penggunaan sumber daya yang paling efektif, produktif, penuh kasih, berorientasi pada hasil dan efisien, sangat penting bahwa para mitra harus mengadopsi satu kerangka kerja tindakan yang menyediakan dasar untuk mengkoordinasikan kerja semua mitra; menempatkan dan memanfaatkan secara maksimal satu badan koordinasi nasional atau masyarakat dengan mandat dari berbagai sektor atau pemangku kepentingan, dan menyepakati satu mekanisme pemantauan dan evaluasi nasional tunggal untuk memastikan dan mempertahankan standar yang diterima (Out dan Mmom, 2015) .

Dengan demikian, hasil yang lebih besar harus direalisasikan jika perjanjian atau kontrak KPS disusun sedemikian rupa sehingga tidak menempatkan mayoritas miskin dalam setiap kerugian sosial, ekonomi dan atau politik. Selain itu, menggabungkan kemitraan dengan pendekatan inovatif yang kredibel dan diterima kelompok untuk pendanaan dan mobilisasi memiliki potensi untuk meningkatkan akses keseluruhan ke layanan-layanan penting berdasarkan struktur kontrak yang sudah ada. Agar pemerintah dapat memaksimalkan manfaat PPP, perlu ada kerangka legislatif yang memadai dan lingkungan yang memungkinkan untuk partisipasi sektor swasta. Komitmen para pemangku kepentingan terhadap PPP akan dicapai dengan berfokus pada operasi mikro, kecil dan menengah, melibatkan kepemimpinan masyarakat seperti asosiasi pengembangan masyarakat, serikat kota, organisasi non-pemerintah, pemerintah daerah, negara bagian dan / atau pemerintah daerah termasuk perusahaan Pariwisata swasta operator (Abiola, dan Francis, 2011). 
Di antara elemen-elemen kunci yang diidentifikasi dalam berbagai definisi internasional kerjasama kemitraan adalah, antara lain, kontrak antara entitas pemerintah dan pemasok sektor swasta (seringkali fitur utamanya); ketentuan dari infrastruktur atau layanan publik melalui sektor swasta; transfer risiko yang substansial ke sektor swasta; remunerasi ke sektor swasta melalui aliran pembayaran dari pemerintah, biaya pengguna dikenakan pada pengguna akhir atau kombinasi keduanya; jangka menengah hingga jangka panjang dari 5 hingga 30 tahun; dan, spesifikasi hasil di mana pembayaran aktual mitra swasta terkait dengan kepatuhan spesifikasi kualitas dan kuantitas yang ditetapkan secara kontrak. Karakteristik penting dari PPP adalah outsourcing dan 'bundling' proyek komponen pengiriman (seperti desain, bangunan, pembiayaan, operasi atau rehabilitasi) yang terstruktur seperti itu sebagai insentif bagi operator pembangun untuk memasukkan pertimbangan biaya operasi jangka panjang dalam fase desain dan konstruksi proyek dengan hasil nilai uang (Rogerson, 2016).

Implementasi proyek-proyek yang bertujuan menciptakan infrastruktur berdasarkan kesepakatan yang telah dibuat dalam pariwisata, memungkinkan untuk menyimpulkan bahwa mekanisme interaksi antara bisnis-swasta dan otoritas negara efektif dalam melaksanakan proyek-proyek infrastruktur besar. Interaksi antara negara dan bisnis secara publik-swasta kemitraan dapat menjadi salah satu bidang yang paling menjanjikan untuk mengintensifkan pengembangan pariwisata (Zaitseva, Larionova, Semenova; Jidkov \& Dashkova, 2017). Dengan dukungan kompeten oleh pemerintah bisnis pariwisata, peningkatan arus wisatawan dan perkembangan ekonomi daerah akan dipastikan keberhasilannya. Melibatkan sektor swasta dalam mengimplementasikan proyek infrastruktur publik akan secara signifikan mengurangi risiko keterlambatan proyek dan pembengkakan biaya. Salah satu cara melibatkan sektor swasta dalam implementasi proyek adalah melalui public private partnership (PPP). Dalam lingkungan PPP, otoritas lokal atau pemerintah mengadakan perjanjian kontrak jangka panjang dengan pemasok swasta untuk pengiriman beberapa layanan. Pemasok bertanggung jawab untuk 
membangun infrastruktur, membiayai investasi, dan mengelola serta memelihara fasilitas.

Ada beberapa alasan mengapa pemerintah semakin mengadopsi pendekatan PPP pembangunan infrastruktur. Pertama, ada kebutuhan mendesak untuk fasilitas infrastruktur. Hal ini disebabkan karena itu sebaga solusi kesenjangan infrastruktur yang besar dan berkembang. Kedua, dengan kendala keuangan utama pada pemerintah di Indonesia, seperti di banyak tempat lain di dunia, PPP telah bergeser dari sekadar pilihan kebijakan penyediaan infrastruktur menuju secara progresif menjadi preferensi kebijakan pemerintahan. Ketiga, menyarankan untuk meningkatnya minat pada PPP berkaitan dengan kegagalan model pengadaan tradisional di masa lalu sebagai konsekuensi dari kurangnya transparansi, penyuapan dan korupsi, dan kurangnya ketersediaan teknologi paling mutakhir.

Implementasi Public Private Partnership sudah dilaksanakan di destinasi wisata di Indonesia, diantaranya adalah obyek wisata sebagai berikut:

Tabel 2 Implementasi Public Private Partnership sudah dilaksanakan di destinasi wisata di Indonesia

\begin{tabular}{|c|c|c|c|}
\hline No & Lokasi & $\begin{array}{c}\text { Kunci Keberhasilan/ } \\
\text { Kegagalann }\end{array}$ & $\begin{array}{c}\text { Aktor } \\
\text { Utama/Penggerak }\end{array}$ \\
\hline 1 & $\begin{array}{l}\text { Telaga } \\
\text { Sarangan } \\
\text { (Pratiwi dan } \\
\text { Warsono, } \\
2013 \text { ). }\end{array}$ & $\begin{array}{l}\text { Pemerintah telah menjalin } \\
\text { kerjasama atau kemitraan } \\
\text { dalam pengembangan } \\
\text { pariwisata telaga sarangan } \\
\text { dengan membuat tim } \\
\text { pengembang pariwisata. } \\
\text { Kerjasama juga terjalin } \\
\text { dengan Karisma Pawirogo } \\
\text { yang bertujuan untuk } \\
\text { pengembangan destinasi } \\
\text { wisata Telaga Sarangan } \\
\text { Magetan. Bentuk kemitraan } \\
\text { untuk pengembangan wisata } \\
\text { Telaga Sarangan adalah }\end{array}$ & $\begin{array}{l}\text { Pemerintah, Pihak } \\
\text { Swasta dan } \\
\text { Masyarakat }\end{array}$ \\
\hline
\end{tabular}


Jurnal Dinamika Ekonomi Syariah

http://ejurnal.iaipd-nganjuk.ac.id/index.php/es

p-ISSN: 2654-3567

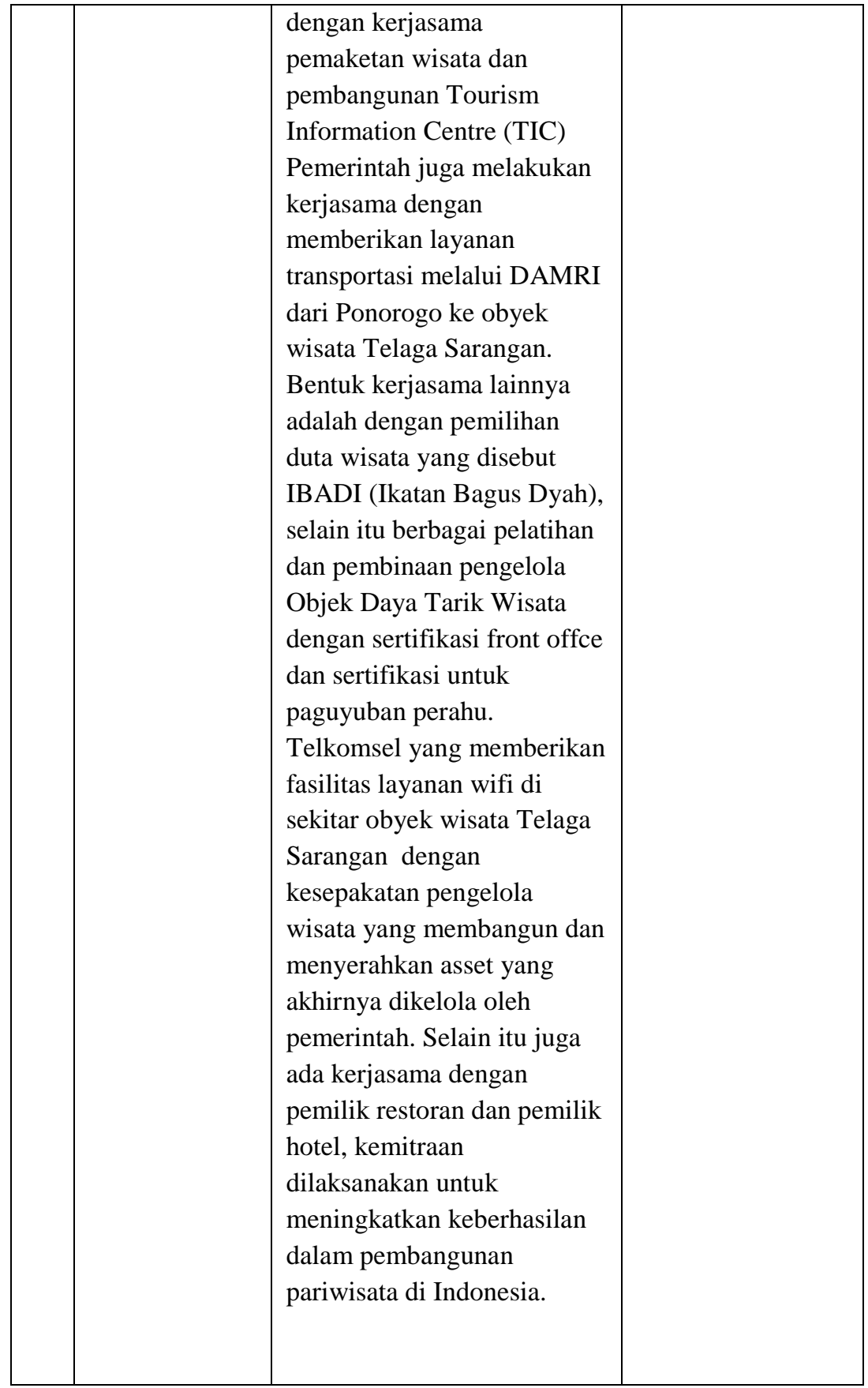


Jurnal Dinamika Ekonomi Syariah

http://ejurnal.iaipd-nganjuk.ac.id/index.php/es

p-ISSN: 2654-3567

\begin{tabular}{|c|c|c|c|}
\hline 2 & $\begin{array}{l}\text { Wisata } \\
\text { Kabupaten } \\
\text { Kuantan } \\
\text { Singingi } \\
\text { (Ikram, 2018) }\end{array}$ & $\begin{array}{l}\text { Public Private Partnership } \\
\text { (Kemitraan pemerintah- } \\
\text { swasta) dalam } \\
\text { pengembangan dan } \\
\text { pengelolaan sektor } \\
\text { pariwisata kurang maksimal, } \\
\text { pengelolaan sarana dan } \\
\text { prasarana yang kurang baik } \\
\text { sehingga menyebabkan } \\
\text { kurangnya wisatawan yang } \\
\text { berkunjung, promosi yang } \\
\text { dilakukan oleh Dinas } \\
\text { Pariwisata dan Kebudayaan } \\
\text { Kabupaten Kuantan Singingi } \\
\text { tentang event pariwisata } \\
\text { pacu jalur dan objek wisata } \\
\text { lainnya yang belum optimal, } \\
\text { serta kurangnya sosialisasi } \\
\text { dari Dinas Pariwisata dan } \\
\text { kebudayaan Kabupaten } \\
\text { Kuantan Singingi terhadap } \\
\text { masyarakat mengenai } \\
\text { budaya dan tradisi, serta } \\
\text { keindahan event pacu jalur } \\
\text { yang belum banyak } \\
\text { diketahui oleh masyarakat } \\
\text { luar daerah dan luar kota. }\end{array}$ & $\begin{array}{l}\text { Dinas kebudayaan } \\
\text { Pariwisata Pemuda } \\
\text { dan Olahraga } \\
\text { Kabupaten } \\
\text { Kuantan Singingi, } \\
\text { pihak swasta dan } \\
\text { masyarakat. }\end{array}$ \\
\hline 3 & $\begin{array}{l}\text { Bali Elephant } \\
\text { Camp, Desa } \\
\text { Wisata } \\
\text { Carangsari, } \\
\text { Kecamatan } \\
\text { Petang, } \\
\text { Kabupaten } \\
\text { Badung } \\
\text { (Dwi Pebriani. } \\
\text { Erviantono. }\end{array}$ & $\begin{array}{l}\text { Kemitraan pengembangan } \\
\text { sektor pariwisata (studi } \\
\text { kasus: Bali Elephant Camp, } \\
\text { Desa Wisata Carangsari, } \\
\text { Kecamatan Petang, } \\
\text { Kabupaten Badung) } \\
\text { kemitraan antara pemerintah } \\
\text { dengan swasta belum } \\
\text { berjalan secara optimal. } \\
\text { Namun dijalankan hanya }\end{array}$ & $\begin{array}{l}\text { Pemerintah, pihak } \\
\text { swasta dan } \\
\text { masyarakat. }\end{array}$ \\
\hline
\end{tabular}


Jurnal Dinamika Ekonomi Syariah

http://ejurnal.iaipd-nganjuk.ac.id/index.php/es

p-ISSN: 2654-3567

\begin{tabular}{|c|c|c|c|}
\hline & $\begin{array}{l}\text { Dwi } \\
\text { Wismayanti, } \\
\text { 2016) }\end{array}$ & $\begin{array}{l}\text { berdasarkan dua prinsip } \\
\text { kemitraan saja yaitu prinsip } \\
\text { kesetaraan dan azas manfaat } \\
\text { bersama. Pola kemitraan } \\
\text { pengembangan sektor } \\
\text { pariwisata di Bali Elephant } \\
\text { Camp tidak memiliki } \\
\text { bentuk, akan tetapi } \\
\text { kemitraan yang berlangsung } \\
\text { berjalan sesuai dengan asas } \\
\text { kekeluargaan dimana setiap } \\
\text { kesepakatan dalam } \\
\text { menjalankan kegiatan } \\
\text { kemitraan terkait } \\
\text { pengembangan pariwisata } \\
\text { tersebut dijalankan secara } \\
\text { kekeluargaan }\end{array}$ & \\
\hline 4 & $\begin{array}{l}\text { Kawasan } \\
\text { Wisata Bahari } \\
\text { Lamongan } \\
\text { (Khitam, } \\
\text { 2012) }\end{array}$ & $\begin{array}{l}\text { Model kerjasama yang } \\
\text { dilakukan antara Pemerintah } \\
\text { Daerah Kabupaten } \\
\text { Lamongan dengan Pihak } \\
\text { swasta PT. Bunga Wangsa } \\
\text { Sejati dalam pengembangan } \\
\text { Kawasan Wisata Bahari } \\
\text { Lamongan menggunakan } \\
\text { Model BOT (Build Operate } \\
\text { and Transfer) sesuai dengan } \\
\text { perjanjian. } \\
\text { Kerjasama yang dilakukan } \\
\text { oleh Pemerintah Daerah } \\
\text { Kabupaten Lamongan } \\
\text { mempunyai pola kontrak } \\
\text { kerja. }\end{array}$ & $\begin{array}{l}\text { Pemerintah, pihak } \\
\text { swasta dan } \\
\text { masyarakat. }\end{array}$ \\
\hline 5 & $\begin{array}{l}\text { Destinasi } \\
\text { Wisata di } \\
\text { Kabupaten }\end{array}$ & $\begin{array}{l}\text { Peran pihak pemerintah dan } \\
\text { swasta sudah berjalan } \\
\text { dengan optimal dengan }\end{array}$ & $\begin{array}{l}\text { Pemerintah, pihak } \\
\text { swasta dan } \\
\text { masyarakat. }\end{array}$ \\
\hline
\end{tabular}




\begin{tabular}{|c|c|c|c|}
\hline & $\begin{array}{l}\text { Pulau Morotai } \\
\text { (Cahyo, 2018) }\end{array}$ & $\begin{array}{l}\text { terpenuhinya empat dari } \\
\text { lima peran dasar pemerintah } \\
\text { dan dua dari lima peran } \\
\text { dasar sektor swasta. Dalam } \\
\text { urusan koordinasi antar } \\
\text { lembaga terkait evaluasi dan } \\
\text { kontrol terhadap } \\
\text { pembangunan, peran sentral } \\
\text { dilakukan oleh DN KEK. } \\
\text { Dalam pelaksanaannya } \\
\text { pembangunan KEK Morotai } \\
\text { yang menjadi poros bagi } \\
\text { perkembangandestinasi } \\
\text { wisata di Kabupaten Pulau } \\
\text { Morotai. Pemerintah pusat } \\
\text { Republik Indonesia secara } \\
\text { keseluruhan masih } \\
\text { mendominasi jumlah } \\
\text { program yang dilaksanakan } \\
\text { terkait pengembangan } \\
\text { destinasi wisata Kabuaten } \\
\text { Pulau Morotai. }\end{array}$ & \\
\hline 6 & $\begin{array}{l}\text { Pengembangan } \\
\text { Wisata } \\
\text { Geopark } \\
\text { Ciletuh- } \\
\text { Palabuhan } \\
\text { Ratu } \\
\text { Kabupaten } \\
\text { Sukabumi } \\
\text { (Apriliani, } \\
\text { Rahmawati } \\
\text { dan Azahari, } \\
\text { 2018) }\end{array}$ & $\begin{array}{l}\text { Kemitraan Pemerintah- } \\
\text { Swasta dalam } \\
\text { pengembangan Geopark } \\
\text { Ciletuh-Palabuhanratu } \\
\text { Kabupaten Sukabumi } \\
\text { dianggap baik. Sumberdaya } \\
\text { termasuk informasi, sumber } \\
\text { daya manusia, masih perlu } \\
\text { ditingkatkan. Namun Dari } \\
\text { Segi Sumber Daya, terutama } \\
\text { dalam pengawasan dan } \\
\text { pengelolaan geosite, } \\
\text { Geopark Ciletuh- } \\
\text { Palabuhanratu cukup luas, } \\
\text { perlu upaya untuk }\end{array}$ & $\begin{array}{l}\text { Pemerintah, pihak } \\
\text { swasta dan } \\
\text { masyarakat. }\end{array}$ \\
\hline
\end{tabular}


Jurnal Dinamika Ekonomi Syariah

http://ejurnal.iaipd-nganjuk.ac.id/index.php/es

p-ISSN: 2654-3567

\begin{tabular}{|l|l|l|}
\hline & meningkatkan kapasitas & \\
pengelolaan sumber daya & \\
manusia dan OPD terlibat & \\
dalam pengembangan & \\
kawasan geopark cileuh- & palabuhanratu. & \\
\hline
\end{tabular}

\section{Pengembangan Pariwisata}

Pengembangan sector pariwisata sebagai upaya untuk menngkatkan, mengelola obyek wisata daya tariknya agar lebih terkenal di berbagai daerah maupun manca negara, hal ini dilakukan karena tiap daerah memiliki keindahan alam yang beragam sehingga dapat menarik simpati wisatawan untuk datang dan menikmati indahnya Indonesia. Dengan demikian diperlukan pembangunan untuk memberikan pelayanan terbaik pada wisatawan agar aman, nyaman dan tenang untuk tinggal. (Primadany dan Riyanto, 2013).

Mengingat kebijakan pembangunan pariwisata pada sumber daya alam dan sumber daya manusia maka diharuskan segera untuk pengembangan pariwisata di Indonesia dengan jalan:

Pertama, membuat program pengembangan destinasi wisata, Program dibuat oleh Dinas Kebudayaan Pariwisata Pemuda dan Olahraga dengan menngkatkan sarana dan prasarana agar devisa daerah dapat menngkat dengan adanya obyek wisata setempat. Sarana Prasarana pariwisata sebaga unsur yang perlu untuk diperhatkan dan pengembangannya, karena akan meningkatkan jumlah pengunjung. Dengan demikian, sarana prasarana yang lengkap dapat membuat wisatawan atau pengunjung lebih nyaman dan bersedia untuk berkunjung ulang ke tempat wisata.

Kedua, meningkatkan sarana prasarana wisatawan. Sarana wisata sebagai suatu yang dapat dimanfaatkan untuk kegiatan wisata dan fasilitas yang dapat diberikan kepada pengunjung atau wisatawan secara langsung ataupun tidak langsung. Perkembangan sarana prasarana pariwisata tergantung pada jumlah pengunjung wisata, sehingga dalam pelaksanaannya pengelola wisata harus bisa memberikan kenyamanan sebagai prioritas utama pagi wisatawan 
asing maupun lokal, memberikan harga yang murah dalam pembelian tiketnya. Selain itu pengelola wisata juga harus dapat menarik hati pengunjung agar tetap betah dan senang untuk berkunjung lebih dari satu kunjungan, sehingga dapat membuat pengunjung ketagihan untuk datang berulang kali ke obyek wisata. Pengelola wisatawan harus dapat memenuhi kebutuhan pengunjung sesuai dengan karakteristik dari destinasi obyek wisata yang dikembangkan.

Sarana prasarana wisata terdiri dari tempat penginapan pengunjung, tempat restoran, tempat belanja misalnya toko-toko souvenir dan pusat oleh-oleh dan beberapa fasilitas umum yang disediakan di obyek wisata misalnya tempat parkir, toilet, musholla dan sebaganya (Shucaina, 2014). Dengan demikian, adanya sarana dan prasarana di obyek wisata sangat penting terutama dalam memberikan pelayanan pada wisatawan yang sedang berkunjung.

Operator layanan pariwisata, agen perjalanan, hotel dan layanan lainnya, dan juga sektor pendukung pariwisata memiliki fungsi yang sama dalam kegiatan pariwisata, sehingga dapat didefinisikan sebagai sektor swasta dalam kegiatan pariwisata. Sektor swasta memberikan pajak dan retribusi kepada pemerintah. Investasi sektor swasta untuk implementasi pariwisata memberikan manfaat ekonomi bagi objek-objek wisata, yang manfaatnya akhirnya berdampak positif bagi semua pihak (Fafurida, 2017).

Untuk mendapatkan keberhasilan public private partnership dalam pengembangan pariwisata di Indonesia, ada beberapa hal yang harus dilakukan yaitu: 1) menciptakan pariwisata yang siap bersaing, mengupayakan obyek wisata yang siap berkompetisi dengan obyek wisata yang ada di Indonesia. 2) menciptakan pariwisata yang kooperatif yaitu obyek wisata yang bisa menciptakan suasana yang asri dan alami, untuk membuat obyek wisata tersebut dibutuhkan kerjasama antara pemerintah dan pihak swasta agar dapat berperan aktif memberikan pelayanan yang terbaik untuk wisatawan dengan pembangunan berbagai prasarana yang menarik. 3) menciptakan pariwisata dengan koordinasi dan kolaborasi yang baik antara masyarakat, pemerintah dan swasta, agar dapat memberikan 
karakteristik yang unik yang dapat mengembangkan obyek wisata alam yang murni (Ikram, 2018).

Obyek pariwisata yang sudah bagus, dalam prosesnya mempunyai tahapan pengelolaan yang jelas. Fungsi manajemen dilaksanakan dengan efektif, sehingga kinerja pariwisata semakin baik. Tersusun jelas dalam program dan terlihat jelas dalam pelaksanaannya (Setyawati dan Safitri, 2019). Peran dari berbagai pihak yang terstruktur dengan baik, dapat menunjukkan keberhasilan dari pengembangan pariwisata yang ada. Semua pihak dapat bergerak dan bersatu dengan kepentingan yang sama, visi dan misi yang berorientasi pada pengembangan wisata dan daya tarik yang selanjutnya menentukan tujuan bersama, sehingga peningkatan industry pariwisata memperoleh dukungan yang baik dari pihak pemerintah, swasta dan masyarakat. Dengan demikian, obyek wisata dapat berkembang dengan maksimal secara internal akan terbentuk ciri khas obyek wisata masing-masing daerah dapat terlaksana, sehingga mampu berkompetisi dan menggait wisatawan asing untuk berkunjung.

\section{Kesimpulan}

Hasil penelitian ini menunjukkan bahwa pengembangan obyek wisata Public Private Partnership (PPP) merupakan hubungan kerjasama antara pemerintah dan pihak swasta sebagai investor dengan berbagai keahlian baik secara teknik, operasional maupun secara inovasi dalam perjalanan bisnis secara efisien dan pemerintah sebagai pembuat kebijakan dalam pembangunan destinasi wisata. Pengembangan pariwisata di Indonesia dengan jalan: 1) membuat program pengembangan destinasi wisata, 2) meningkatkan sarana prasarana wisatawan.

Untuk mendapatkan keberhasilan public private partnership dalam pengembangan pariwisata di Indonesia, ada beberapa hal yang harus dilakukan yaitu: 1) menciptakan pariwisata yang siap bersaing, mengupayakan obyek wisata yang siap berkompetisi dengan obyek wisata yang ada di Indonesia. 2) menciptakan pariwisata yang kooperatif yaitu obyek wisata yang bisa menciptakan suasana yang 
asri dan alami, untuk membuat obyek wisata tersebut dibutuhkan kerjasama antara pemerintah dan pihak swasta agar dapat berperan aktif memberikan pelayanan yang terbaik untuk wisatawan dengan pembangunan berbagai prasarana yang menarik. 3) menciptakan pariwisata dengan koordinasi dan kolaborasi yang baik antara masyarakat, pemerintah dan swasta, agar dapat memberikan karakteristik yang unik yang dapat mengembangkan obyek wisata alam yang murni.

\section{Daftar Pustaka}

Abiola, A. G. and Francis, O. A. (2011). Towards a Public Private Partnership in the Nigerian Power Sector: Challenges and Prospects. A paper presented at the 4th Annual Nigerian Association for Energy Economics/International Association for Energy Economics (NAEE/IAEE) International Conference Green Energy and Energy Security: Options for Africa Sheraton Hotel \& Towers, Abuja, Nigeria, April 27-29

Dias, Cheryl Venan (2014) Public Private Partnership In Tourism - An Opportunity For Goa, https://www.researchgate.net/publication/305719473

Ekpenyong, Out dan Prince C. Mmom (2015) Public-Private Partnership and Tourism Development in the Niger Delta Region Journal of Environment and Earth Science www.iiste.org Vol.5, No.2, 201580

Fafurida, Izzatun Ni'mah (2017) Public-Private Partnership to Increase Economic Growth of Tourism Sector Jurnal Ekonomi Pembangunan, 18 (1), 2017, 1-18

Fitriyah, Faridah (2016) Model Public Private Partnership Dalam Peningkatan Pelayanan Sumber Daya Air Bersih Di Pdam Kabupaten Gresik, Kebijakan dan Manajemen Publik, Volume 4, Nomor 1

Haddadi, Mahdi. (2015). The Role of Public Private Partnership Contracts in Tourism Industry Development. Tehran: Journal of 
Academic Research in Economics and Management Sciences. Vol.4, No.1

Holik, Abdul. (2016). Relationship of Economic Growth with Torism Sector. JEJAK. Vol.9 (i) (2016): 16-32. DOI: http://dx.doi. org/10.15294/jejak.v9i1.6652.

Ikram, Muhammad, (2018) Public Private Partnership Dalam Pengembangan Potensi Wisata Di Kabupaten Kuantan Singingi Tahun 2011-2015, JOM FISIP Vol. 5 No. 1

Johnson, W. (2010). Public Enterprises, Engine of Development. International Journal of Sustainable Development, 4(2): 51-59.

Latuconsina, Olivia CH, Yusman Syaukat dan Hermanto Siregar (2013) Strategi Pembiayaan Terhadap Pengembangan Pariwisata Berbasis Masyarakat Di Kota Ambon Jurnal Manajemen Pembangunan Daerah.. Volume 5 Nomor 2

Maha Rani, Deddy Prasetya (2014) Pengembangan Potensi Pariwisata Kabupaten Sumenep, Madura, Jawa Timur (Studi Kasus: Pantai Lombang). Jurnal Politik Muda, Vol. 3 No. 3

Pratiwi, Nina Galih dan Hardi Warsono (2013) Analisis PublicPrivate Partnership Dalam Pengembangan Objek Wisata Telaga Sarangan Di Kabupaten Magetan. Departemen Administrasi Publik Fakultas Ilmu Sosial dan Ilmu Politik Universitas Diponegoro

Primadany, Sefira Ryalita, Mardiyono dan Riyanto (2013) Analisis Strategi Pengembangan Pariwisata Daerah (Studi pada Dinas Kebudayaan dan Pariwisata Daerah Kabupaten Nganjuk) Jurnal Administrasi Publik (JAP), Vol. 1, No. 4.

Rogerson, Christian M (2016) Public-private partnerships for tourism infrastructure development: Evidence from the Cradle of Humankind, South Africa, Toursm, Vol. 64/ No. 4

Setyawati, Rahmi, dan Karin Amelia Safitri (2019) Pengembangan Wisata Di Kabupaten Buru Menggunakan Analisis Swot. Jurnal Sosial Humaniora Terapan Volume 1 No.2

Suardana, I Wayan (2013) Analisis Kebijakan Pengembangan Pariwisata (Intervensi melalui Kebijakan Pariwisata 
Jurnal Dinamika Ekonomi Syariah http://ejurnal.iaipd-nganjuk.ac.id/index.php/es p-ISSN: 2654-3567

Berkelanjutan di Bali), Udayana Universty, https://www.researchgate.net/publication/301514282

Tshehla, Makgopa F . (2018) Constraints for Successful Implementation of PublicPrivate Partnership (PPP) for Tourism Infrastructure Projects, African Journal of Hospitality,Tourismand Leisure, Volume 7

World Travel Tourism Council., (2011), "Travel \& Tourism”, The Authority on World Travel and Tourism, pp. 29

Zaitseva, Natalia Alexandrovna, Anna Anatolyevna Larionova, Lyudmila Valerievna Semenova; Aleksey Sergeevich Jidkov, Elena Valerievna Dashkova (2017) Realization of projects of public-privatepartnership in tourism and services inthe Russian FederationRealización de proyectos de asociación privada-pública enturismo y servicios en la Federación Rusa, Vol. 38 (No 49) 